University of Nebraska - Lincoln

DigitalCommons@University of Nebraska - Lincoln

8-1987

\title{
Population Dynamics of the Parasites in Fundulus zebrinus in the Platte River of Nebraska
}

John J. Janovy Jr.

University of Nebraska - Lincoln, jjanovy1@unl.edu

Eugene Lee Hardin

Women's Health Care of Western Colorado

Follow this and additional works at: https://digitalcommons.unl.edu/bioscijanovy

Part of the Parasitology Commons

Janovy, John J. Jr. and Hardin, Eugene Lee, "Population Dynamics of the Parasites in Fundulus zebrinus in the Platte River of Nebraska" (1987). John Janovy Publications. 19.

https://digitalcommons.unl.edu/bioscijanovy/19

This Article is brought to you for free and open access by the Papers in the Biological Sciences at DigitalCommons@University of Nebraska - Lincoln. It has been accepted for inclusion in John Janovy Publications by an authorized administrator of DigitalCommons@University of Nebraska - Lincoln. 


\title{
POPULATION DYNAMICS OF THE PARASITES IN FUNDULUS ZEBRINUS IN THE PLATTE RIVER OF NEBRASKA
}

\author{
John Janovy, Jr. and E. L. Hardin \\ School of Biological Sciences, University of Nebraska-Lincoln, Lincoln, Nebraska 68588-0118
}

ABSTRACT: The population dynamics of 7 parasite species or ecotypes were studied in the plains killifish, Fundulus zebrinus, at a single collection site in the South Platte River of Nebraska, U.S.A., for 5 yr. Parasites were: Myxosoma funduli (gill), Trichodina sp. (gill), Gyrodactylus bulbacanthus (gill), Urocleidus fundulus (gill), Gyrodactylus stableri (body surface), and Neascus sp. (=Posthodiplostomum; eyes and body cavity). Parasite densities, prevalences, and variance/mean ratios are reported for 22 samples, totalling 447 fish, over the summer months. Positive correlations were obtained between density and both standardized prevalence and log-transformed variance. Urocleidus fundulus populations were relatively stable with low densities and low variance/ mean ratios. Most other species' populations exhibited disproportionate increases in aggregation with increases in density. The Neascus species showed long-term decreases in density and prevalence associated with increases in river flow rates.

In the Platte River system of Nebraska, Fundulus zebrinus ( $=F$. kansae Garman; see Poss and Miller, 1983) is host to a number of parasite species (Knight et al., 1980; Adams, 1985). Observations made from 1975 through 1981 suggested that these formed an assemblage whose members' population structures varied with collection date and site (Adams, 1985, and unpubl. data). The Platte system is a physical environment that is highly complex and variable, although both of these attributes are primarily functions of streamflow. The river thus provides an opportunity to investigate the dynamic behavior of several parasite species populations in a single host species, all in a fluctuating environment.

\section{THE STUDY AREA}

The geographical features of the Platte and South Platte rivers in central Nebraska have been previously described by Adams (1985) and Knight et al. (1977, 1980). In the present study, samples were taken from a $2-\mathrm{km}$ stretch of the South Platte River $5 \mathrm{~km}$ east of Roscoe, Nebraska. Streamflow varies substantially both on an annual and seasonal basis (Bentall, 1975). At lower flow rates (less than $500 \mathrm{cubic} \mathrm{ft} / \mathrm{sec}$ ), the Platte is a typical braided prairie river with small channels and pools, each with its own physical characteristics. At high rates (above 1,500 cubic $\mathrm{ft} / \mathrm{sec}$ ), the small channels are obliterated.

Received 21 November 1986; revised 23 March 1987; accepted 30 March 1987.

\section{THE HOST/PARASITE SYSTEM}

The host/parasite system consisted of the following: (1) A single fish species that occurred throughout the study area, although occurrence was highly localized and the locations themselves differed depending on the season and year; and (2) 7 different parasite types with a variety of life cycles. These parasites were: Myxosoma funduli Kudo, 1918 (Myxozoa: Myxosporea)-gill tissues; Trichodina sp. (Ciliophora: Peritrichia)gill surface; Urocleidus fundulus Mizelle, 1949 (Monogenea)-gill surface; Gyrodactylus bulbacanthus Mayes, 1977 (Monogenea) - gill surface; Gyrodactylus stableri Hathaway and Herlevich, 1973 (Monogenea)-body surface, mainly fins; Neascus sp. (Posthodiplostomum: Digenea)-eye; Neascus sp. (Posthodiplostomum: Digenea)body cavity.

The 2 larval trematodes are termed eye metacercaria and body cavity metacercaria, respectively, in the following Results and Discussion. Although they are treated as separate ecotypes, there was no structural basis for considering them different species.

\section{QUESTIONS}

With respect to population dynamics, this system allowed consideration of the following questions: (1) What is the relationship between density and aggregation, and between density and prevalence, in the parasite populations? (2) Do the parasite species differ in their distributions among the demographic classes of the host population? (3) Do all the parasite species popula- 
TABLE I. Collection dates and sample sizes for data reported in this paper.

\begin{tabular}{|c|c|c|c|}
\hline Date & $\begin{array}{c}\text { Sample } \\
\text { size }\end{array}$ & Date & $\begin{array}{c}\text { Sample } \\
\text { size }\end{array}$ \\
\hline 1982 & & 1985 & \\
\hline 20 May & 16 & 8 June & 24 \\
\hline 19 July & 16 & 15 June & 24 \\
\hline 2 August & 26 & 27 June & 19 \\
\hline 1983 & & 29 June & 22 \\
\hline 1703 & & I July & 22 \\
\hline 15 June & 11 & 20 July & 22 \\
\hline 11 July & 21 & 10 August & 19 \\
\hline 25 July & 27 & 1986 & \\
\hline 1984 & & 21 May & 24 \\
\hline 1 June & 19 & 4 June & 24 \\
\hline 16 July & 15 & 29 June & 24 \\
\hline 25 July & 8 & 16 July & 14 \\
\hline \multicolumn{4}{|l|}{1985} \\
\hline 20 May & 23 & & \\
\hline 25 May & 27 & & \\
\hline
\end{tabular}

tions respond in similar ways to fluctuating streamflow?

\section{MATERIALS AND METHODS}

Fish were seined and transported to the Cedar Point Biological Station, $13 \mathrm{~km}$ north of Ogallala, Nebraska, where they were measured, sexed, and examined according to the methods of Adams (1985) and Knight et al. (1980). Twenty-two samples, containing a total of 447 fish, were taken over a 5 -year period. Collection dates and sample sizes are given in Table I. Sample sizes were determined by either the number of fish actually captured or the number that could be examined within $72 \mathrm{hr}$ of capture. Fluctuating streamflow did not always allow scheduled sampling or equal sample sizes, but an attempt was made to space collections in order to provide parasite distribution parameter values over a several year period, as well as from repeated samples taken over a relatively short period. Data from the samples listed in Table I are displayed in chronological order in Figures 1-10.

South Platte River discharge rates were obtained from the Nebraska Department of Water Resources (NDWR). Records are from the South Platte gauging station at North Platte, Nebraska, the closest gauging station to the study area with a continuous record over a several year period (see Table II). Streamflow data are summarized by NDWR in several ways and it is not clear which of these ways is most appropriate for use as reference material for biological papers. In this paper, water years (1 October through 30 September) were chosen as the unit for use in comparing demographic makeup of infected and uninfected fish. The water year includes a prior fall when snails are still active during the fall bird migration season (aquatic birds are considered the definitive hosts of the Neascus species), as well as a young-of-the-year class of fish. Water years also take into account a single winter/ summer cycle. South Platte streamflow is determined largely by snowmelt, especially in the spring through
TABLE II. Data illustrating fluctuations in South Platte River streamflow during the study period.

\begin{tabular}{cccc}
\hline \multicolumn{3}{c}{$\begin{array}{c}\text { Average annual daily } \\
\text { discharge rates } \\
\text { (cubic feet/sec) }\end{array}$} & \\
\cline { 2 - 3 } & $\begin{array}{c}\text { Calendar } \\
\text { year }\end{array}$ & Water year* & Water year ends \\
\hline 1980 & 1,438 & 161 & $9 / 30 / 81$ \\
1981 & 162 & 166 & $9 / 30 / 82$ \\
1982 & 171 & 2,316 & $9 / 30 / 83$ \\
1983 & 2,462 & 1,656 & $9 / 30 / 84$ \\
1984 & 1,903 & 884 & $9 / 30 / 85$ \\
1985 & 550 & 730 & $9 / 30 / 86$ \\
\hline
\end{tabular}

* Water years run from 1 October through 30 September. For example, water year 1982 ends on 30 September 1983.

midsummer, and local rainfall does not usually have a major and lasting effect on the river. Thus, during a water year, there is less potential for fluctuations in physical structure of the river than in a calendar year.

Observed parasite distributions were fit to theoretical normal, Poisson, and negative binomial distributions, and prevalence and variance/mean ratios were calculated, according to established methods used by various authors (Bliss, 1953; Pennycuick, 1971; Knight et al., 1977; Taylor et al., 1978, 1979). Variance/mean ratios were used as a measure of aggregation, rather than the negative binomial $k$, because the ratios more accurately reflected the biological property of aggregation resulting from a few heavily infected individuals in a sample. Relationships between density and aggregation were determined by the methods of Taylor et al. (1978), using regression lines calculated from logtransformed means and variances (Table III). Relationships between density and prevalence (Table IV) were determined using regression lines calculated from standardized variables ( $z$ scores of means and prevalences) according to the methods of Dixon and Massey (1957).

For the purpose of demographic comparisons, host length and sex were considered the relevant attributes and samples from low- and high-water years were lumped to increase sample size for analysis. Collections from 1982, 1985, and 1986 (WY 1981, 1984, and 1985) were considered to be from low-water years, and those from 1983 and 1984 (WY 1982 and 1983) were considered to be from high-water years (see Table II). Length comparisons were based on a $t$-test of the null hypothesis: there is no difference between the mean length of infected fish and that of noninfected fish. Significance of differences between prevalence in the 2 sexes was determined using a $2 \times 2$ contingency table to test an analogous null hypothesis.

Terminology in this paper is consistent with the recommendations of Margolis et al. (1982).

\section{RESULTS}

Parasite populations were typically overdispersed (variance greater than mean) except for the following individual samples: eye metacercaria for 20 May and 27 June 1985, body cavity metacercaria for 10 August 1985, and G. bul- 

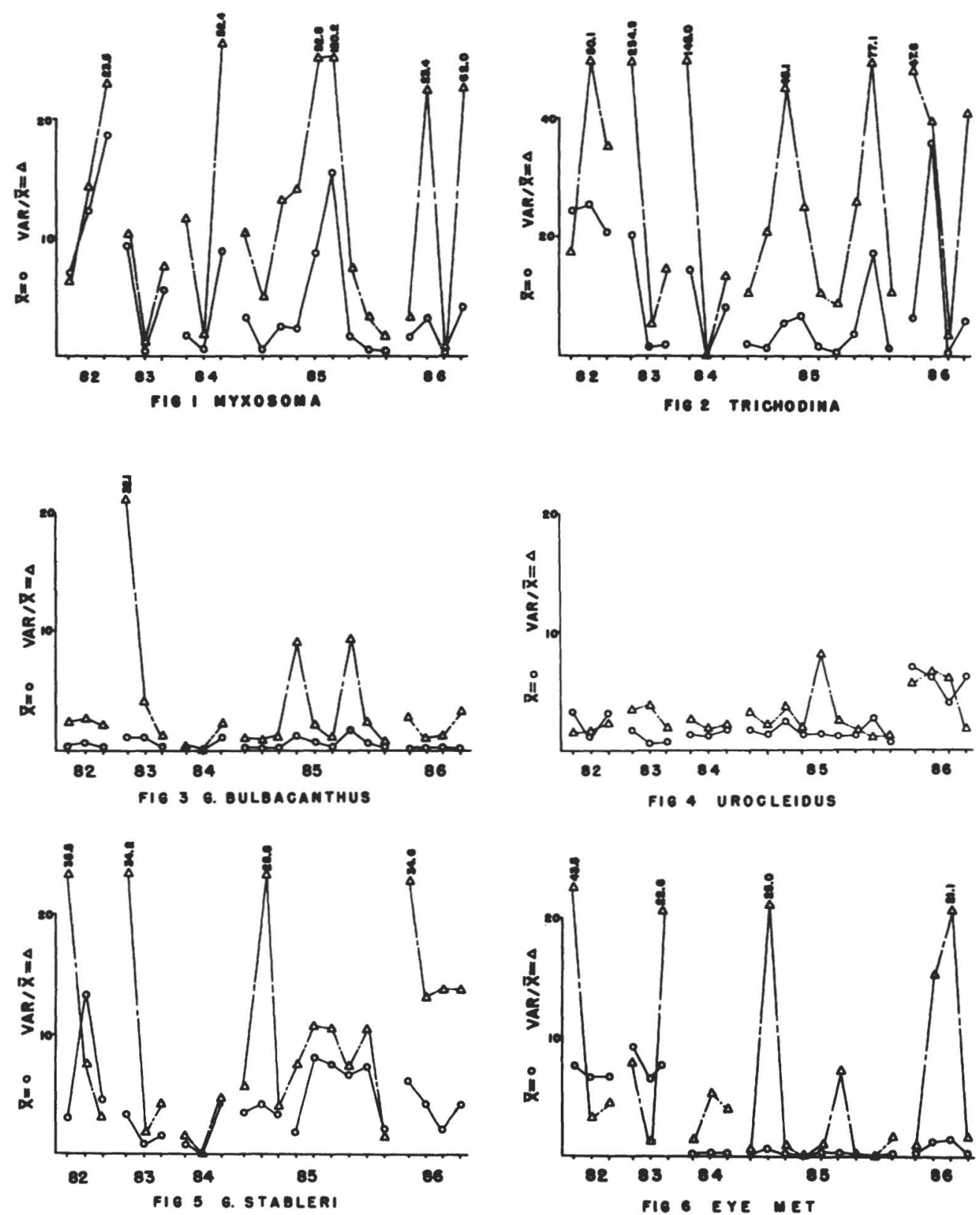

Figures 1-6. 1. Densities (=mean) $(0)$ and variance/mean ratios $(\Delta)$ for Myxosoma funduli for 22 collections from 1982 to 1986. In Figures 1-7, if the variance/mean ratio is greater than 20, the value of the ratio is given above the data point. 2. Densities $(0)$ and variance/mean ratios $(\Delta)$ for Trichodina sp. for 22 collections from 1982 to 1986. 3. Densities $(O)$ and variance/mean ratios $(\triangle)$ for Gyrodactylus bulbacanthus for 22 collections from 1982 to 1986. 4. Densities $(O)$ and variance/mean ratios $(\Delta)$ for Urocleidus fundulus for 22 collections from 1982 to 1986. 5. Densities $(O)$ and variance/mean ratios $(\Delta)$ for Gyrodactylus stableri for 22 collections from 1982 to 1986 . 6. Densities $(O)$ and variance/mean ratios $(\triangle)$ for eye Neascus for 22 collections from 1982 to 1986 .

bacanthus for 20 May and 10 August 1985. In a few samples of some parasites, mean, variance, and prevalence were very low (range 0.04-0.08 for all parameter values) and equal, giving vari- ance/mean ratios of 1 . Of the 3 distribution models tested, the negative binomial was the one of best fit in cases with variance greater than mean; however, goodness-of-fit chi-square val- 



FIGURES 7-10. 7. Densities $(O)$ and variance/mean ratios $(\triangle)$ for body cavity Neascus for 22 collections from 1982 to 1986. 8. Prevalence of Myxosoma funduli $(O)$ and Urocleidus fundulus $(\triangle)$ in 22 collections from 1982 to 1986. 9. Prevalence of Trichodina sp. (O), Gyrodactylus bulbacanthus ( $\square$ ), and G. stableri $(\triangle)$ in 22 collections from 1982 to 1986 . 10. Prevalence of eye (O) and body cavity ( $\square)$ Neascus in 22 collections from 1982 to 1986.

ues were usually too high to conclude that the values of mean and $\mathrm{k}$ obtained accurately described the individual sample parasite populations, or that the normal or Poisson values accurately described distributions with variance less than mean. In every sample with a high variance/ mean ratio, that property resulted from the presence of 1 or a few heavily infected fish.

Collection year, prevalence, mean (=density), and population aggregation expressed as variance/mean ratios are shown in Figures 1-10. The various parasite species populations exhibited 2 general kinds of dynamic behavior: (1) fluctuations in density, prevalence, and aggregation within a single year's collections, and (2) relatively long-term changes in density or prevalence, i.e., occurring over a several year period. In some species, e.g., Myxosoma funduli, Trichodina sp., and eye metacercaria (Figs. 1, 2, 6), small changes in density were often accompanied by very large changes in variance/mean ratios, whereas in others, e.g., Urocleidus fundulus and
G. bulbacanthus (Figs. 3, 4), fluctuations in density were tracked more closely by (lower) variance/mean ratios. Some populations also behaved differently depending on the year. In the case of Myxosoma funduli, variance/mean ratios tracked density closely in 1982-1983, but showed disproportionate shifts in magnitude in 19841986 (Fig. 1). These differences between parasite species resulted in the various values for slopes of least-squares lines (Table III) when the data were analyzed according to the methods of Taylor et al. (1978, 1979).

Positive correlations were observed between density and prevalence (Table IV) when both sets of values were standardized, although neither the correlation coefficients nor slopes of regression lines calculated from $z$ scores were particularly high for any species. Only in the case of Neascus sp. were obvious long-term changes in prevalence observed (Fig. 10).

Demographic analysis of the host population revealed that there were significant differences 
TABLE III. Relationship between log-transformed sample means (=densities) (abscissa) and sample variances (ordinate).

\begin{tabular}{|c|c|c|c|c|c|c|}
\hline Parasite ${ }^{*}$ & Slope & $Y$-intercept & $r$ & $\begin{array}{l}\text { Var. due to } \\
\text { regression }\end{array}$ & $\begin{array}{l}\text { Var. about } \\
\text { regression }\end{array}$ & $F(1,20) \dagger$ \\
\hline M. funduli & 1.64 & 1.80 & 0.96 & 145.57 & 0.58 & 251.66 \\
\hline Trichodina sp. & 1.73 & 1.92 & 0.94 & 106.71 & 0.66 & 160.79 \\
\hline G. bulbacanthus & 1.65 & 1.41 & 0.92 & 71.82 & 0.69 & 103.41 \\
\hline$U$. fundulus & 1.33 & 0.73 & 0.87 & 17.75 & 0.29 & 61.19 \\
\hline G. stableri & 1.87 & 0.90 & 0.87 & 42.53 & 0.69 & 61.70 \\
\hline Neascus (eye) & 1.37 & 1.49 & 0.89 & 116.68 & 1.58 & 73.99 \\
\hline Neascus (bc) & 1.50 & 1.65 & 0.95 & 154.86 & 0.87 & 177.65 \\
\hline
\end{tabular}

$*^{*} \mathrm{n}=22$ for all parasites.

$\dagger$ In all cases, the probability of obtaining the observed $F$ values by chance alone if variances were equal is less than 0.001 .

between the sizes of infected and noninfected fish for both high- and low-water conditions for all parasites, with one exception, namely G. stableri in low-water years (Table V). The nature of the differences, however, depended on water conditions. For example, with $M$. funduli and the 2 metacercarial types, infected fish were larger than noninfected ones in high-water years but smaller in low-water years. In high-water years, with the other parasites, infected fish were smaller than noninfected ones, but the size differences varied according to parasite in low-water years.

Contingency table analysis of prevalence vs. sex showed that with the exception of $M$. funduli and $G$. stableri, infections were independent of sex for both high- and low-water years. With $G$. stableri, females were infected more frequently than males in both streamflow conditions, while with $M$. funduli, females were infected more frequently than males in high-, but not in low-water years.

\section{DISCUSSION}

This paper demonstrates that the density/aggregation relationship proposed by Taylor et al.
$(1978,1979)$ holds for several kinds of parasites in a single host species in a fluctuating environment. The parasites' differing transmission mechanisms are an important consideration in assessing the significance of this observation. Price (1980) suggested that the founder effect will be a major contributor to the genetic structure of parasite populations. But life cycle events, such as reproductive rate and ecological requirements of infective stages, influence the manner in which hosts acquire parasites. In this study, at least 3 different transmission mechanisms are represented by the parasites involved. The reported observations, however, reveal that it is the extent rather than the fact of clumping that varies from species to species. Only when prevalence data are examined in conjunction with the density/ aggregation relationships does the potential evolutionary significance of parasite population structure become apparent. For example, over the long term, $U$. fundulus, because of its high prevalence, is exposed to a broad segment of the environmental (=genetic) variation provided by the host. On the other hand, with the Neascus species, larval and snail biology probably con-

TABLE IV. Relationship between z-transformed sample means (=densities) (abscissa) and sample prevalences (ordinate).

\begin{tabular}{|c|c|c|c|c|c|c|}
\hline Parasite* & Slope & $\mathrm{Y}$-intercept & $r$ & $\begin{array}{l}\text { Var. due to } \\
\text { regression }\end{array}$ & $\begin{array}{l}\text { Var. about } \\
\text { regression }\end{array}$ & $F(1,20) \dagger$ \\
\hline M. funduli & 0.64 & $-7.47^{-4}$ & 0.64 & 8.63 & 0.62 & 13.91 \\
\hline Trichodina sp. & 0.87 & $-4.54^{-4}$ & 0.87 & 15.81 & 0.26 & 60.88 \\
\hline G. bulbacanthus & 0.76 & $-5.04^{-11}$ & 0.76 & 12.13 & 0.44 & 27.51 \\
\hline U. fundulus & 0.71 & $9.09^{-4}$ & 0.71 & 10.55 & 0.52 & 20.23 \\
\hline G. stableri & 0.77 & $2.31^{-3}$ & 0.77 & 12.49 & 0.43 & 29.37 \\
\hline Neascus (eye) & 0.94 & $4.27^{-4}$ & 0.94 & 18.59 & 0.12 & 155.45 \\
\hline Neascus (bc) & 0.91 & $-8.69^{-4}$ & 0.91 & 17.47 & 0.18 & 97.83 \\
\hline
\end{tabular}

$* \mathrm{n}=22$ for all parasites.

$\dagger$ The probability of obtaining an $F$ value of 13.91 by chance alone if variances were equal is less than 0.005 . For all other $F$ values, the probability is less than 0.001 . 
TABLE V. Sizes of infected and noninfected fish compared by t-test for high-and low-water years.

\begin{tabular}{|c|c|c|c|c|c|c|}
\hline \multirow[b]{2}{*}{ Parasite } & \multicolumn{3}{|c|}{ Low-water years $(1982,1985,1986)^{*}$} & \multicolumn{3}{|c|}{ High-water years $(1983,1984)$} \\
\hline & Infected & Noninfected & $t \dagger$ & Infected & Noninfected & $t$ \\
\hline M. funduli & $5.97(1.09)$ & $6.21(0.86)$ & 27.24 & $6.35(1.37)$ & $6.26(1.58)$ & 3.02 \\
\hline Trichodina sp. & $6.08(1.00)$ & $6.16(0.94)$ & 10.14 & $6.02(1.40)$ & $6.51(1.42)$ & 17.28 \\
\hline G. bulbacanthus & $6.35(1.38)$ & $6.06(0.84)$ & 25.50 & $6.16(2.88)$ & $6.35(1.19)$ & 4.50 \\
\hline U. fundulus & $6.11(0.84)$ & $6.14(1.37)$ & 3.17 & $6.27(1.38)$ & $6.37(1.60)$ & 3.51 \\
\hline G. stableri & $6.12(0.84)$ & $6.13(1.24)$ & 0.62 & $6.16(1.41)$ & $6.43(1.50)$ & 9.37 \\
\hline Neascus (eye) & $5.78(1.40)$ & $6.23(0.78)$ & 40.53 & $6.59(1.24)$ & $5.74(1.50)$ & 28.87 \\
\hline Neascus (bc) & $5.76(1.43)$ & $6.23(0.78)$ & 44.51 & $6.58(1.46)$ & $5.99(1.32)$ & 21.10 \\
\hline
\end{tabular}

tribute to a situation similar to that postulated by Price (1980), namely a strong founder effect coupled with flush-crash cycles in a patchy environment. In periods of extended drought (late 1970 's through 1982), the parasites come to occupy most of the available patches (individual fish) at a relatively high density (cf. Figs. 6, 7, $10)$, but survive unfavorable times in low density concentrated in a few patches. The differing monogene and strigeoid transmission mechanisms likely play a significant role in dictating the worms' respective population level relationships with their hosts.

Among the parasites studied, $M$. funduli and Trichodina sp. seem to represent the extremes of short-term population instability, with several-fold differences in both prevalence and variance/mean ratios not only between, but also within, years (Figs. 1, 2, 8, 9). In these cases, the long-term pattern of infection is persistence, with intense aggregation, but without the flush-crash cycles suggested by the Neascus data. At least in the case of $M$. funduli, this apparent population characteristic is probably related to transmission mechanism. Knight et al. (1977) demonstrated that young-of-the-year fish are infected, and inferred from that observation that the prepatent period for $M$. funduli was less than 60 days. Shortterm streamflow changes, e.g., resulting from headwaters storms, could easily affect the fish/ spore encounter dynamics. The short-term result is a highly variable distribution of parasite genetic information within the environmental heterogeneity provided by the host population. The long-term result is a situation in which persistence is probably a better measure of parasite success than high density or high prevalence.

Kennedy (1984) reported long-term observations of 3 species of larval strigeoids in a single host species, in a lake system, in which the Taylor et al. $(1978,1979)$ density/aggregation relationships held. But the regression line slopes of 1 of the species was about half that of the other 2 . The slope differences suggested corresponding differences in the dynamics of host/parasite encounter. The present study extends the Kennedy (1984) work to a prairie river and to a set of parasites representing several transmission mechanisms. The fact that in a single host/several parasites system different transmission mechanisms nevertheless generate linear log density/log aggregation relationships (Table III), supports the assertion by Anderson and Gordon (1982) that "the prime cause of overdispersion ... will be stochastic factors of an environmental, as opposed to a demographic, nature." Taken in the context of the present work, the Anderson and Gordon (1982) paper implies that Platte River streamflow fluctuations exert an effect on parasite population structure that is at least somewhat dependent on transmission mechanism.

Demographic analysis of infected and noninfected host populations showed that infected and noninfected fish tended to differ in size (corresponds to age; see Knight et al., 1977), but not in sex, except in a few cases. The figures in Table $V$ suggest an explanation for the size differences with some parasites. The pattern seen in M. fun$d u l i$ and the 2 Neascus species could be produced by a situation in which low water was a favorable transmission environment and young of the year became infected, but in which high water was an unfavorable transmission environment so that infected fish included a large number of individuals from the previous year. The similar sizeyear patterns also imply a similar habitat in which infection is inost likely to occur. In the Platte, that habitat is probably the small pools that are abundant during low-water conditions. The in- 
fection vs. sex analysis reveals 3 types of host/ parasite population level relationships: one in which infection is independent of sex, one in which sex-infection differences are probably of physiological origin (G. stableri), e.g., based on mucus, color, or hormonal factors, and one in which the differences are likely ecological $(M$. funduli). Although the analysis of host demography relative to infection does not provide explanations for parasite population structures, it does reveal some patterns that can serve as a basis for future studies.

The data in this paper are part of a very large set that includes several measures of river characteristics (streamflow summarized according to various intervals of differing parasitological significance), parasite assemblage diversity, and quantification of parasite niche breadths and overlaps. A complete statistical analysis of the effects of fluctuating streamflow on the $F$. zebrinus/parasite assemblage system is beyond the scope of this paper, and properly should await publication of observations on parasite niches and assemblage dynamics. At this stage, however, it can be said that streamflow fluctuations exert strong influences on some parasite species but not on others, that these influences are at least in some cases related to transmission mechanisms, and that the environmental fluctuations reveal differences in parasite population dynamics that may have evolutionary implications.

In summary, the populations of some parasites in $F$. zebrinus experience wide ranges of density, aggregation, and prevalence, while others do not. The literature contains numerous studies of parasite population dynamics, most of which address questions of population regulation (e.g., Holmes et al., 1977; Granath and Esch, 1983; Lemly and Esch, 1984). Others, e.g., Cone and Anderson (1977), Esch et al. (1979), Price (1983), and Kennedy et al. (1986), deal with parasite assemblages as a function of host age, species, or habitat. This paper adds a relatively long-term study of several species' population structure in a fluctuating environment. The basic nature of, and differences between, dynamic changes in the 7 parasites' populations are described, thus providing background data for future considerations of assemblage diversity and the question of interactions between the parasites.

\section{ACKNOWLEDGMENTS}

This study was supported in part by the Nebraska Water Resources Center, UN-L. Help provided by Lee Becker (Nebraska Department of Water Resources), Scott Frogge, Chris Hakenkamp, Gerald Kutish, Ralene Mitschler, Martha Nelson, and Tim Ruhnke is gratefully acknowledged.

\section{LITERATURE CITED}

ADAms, A. M. 1985. Parasites on the gills of the plains killifish, Fundulus kansae, in the South Platte River, Nebraska. Transactions of the American Microscopical Society 104: 278-284.

Anderson, R. M., AND D. M. Gordon. 1982. Processes influencing the distribution of parasite numbers within host populations with special emphasis on parasite-induced host mortalities. Parasitology 85: 373-398.

Bentall, R. (preparator). 1975. Hydrology, Nebraska Mid-State Division, Pick-Sloan Missouri Basin program, and associated areas. UN-L Conservation and Survey Division, Lincoln, Nebraska, $256 \mathrm{p}$.

BLISS, C. I. 1953. Fitting the negative binomial distribution to biological data. Biometrics 9: 176196.

Cone, D. K., And R. C. Anderson. 1977. Parasites of pumpkinseed (Lepomis gibbosus L.) from Ryan Lake, Algonquin Park, Ontario. Canadian Journal of Zoology 55: 1410-1423.

Dixon, W. J., AND F. J. MASSEY. 1957. Introduction to statistical analysis. McGraw-Hill Book Company, New York, 488 p.

EsCH, G. W., J. W. GibBons, AND J. E. BorQue. 1979. The distribution and abundance of enteric helminths in Chrysemys s. scripta from various habitats on the Savannah River Plant in South Carolina. Journal of Parasitology 65: 624-632.

Granath, W. O., AND G. W. EsCh. 1983. Temperature and other factors that regulate the composition and infrapopulation densities of Bothriocephalus acheilognathi (Cestoda) in Gambusia affinis (Pisces). Journal of Parasitology 69: 11161124.

Holmes, J. C., R. P. Hobbs, AND T. S. Leong. 1977. Populations in perspective: Community organization and regulation of parasite populations. In Regulation of parasite populations, G. W. Esch (ed.). Academic Press, New York, pp. 209-245.

KENNEDY, C. R. 1984. The use of frequency distributions in an attempt to detect host mortality induced by infections of diplostomatid metacercariae. Parasitology 89: 209-220.

$\longrightarrow$, A. O. Bush, AND J. M. Aho. 1986. Patterns in helminth communities: Why are birds and fish different? Parasitology 93: 205-215.

KNIGHT, S. A., J. JANOVY, JR., AND W. L. Current. 1977. Myxosoma funduli Kudo, 1918 (Protozoa: Myxosporida) in Fundulus kansae: Summer epizootiology. Journal of Parasitology 63: 897-902.

,, AND $\longrightarrow$ 1980. Myxosoma funduli Kudo, 1918 (Protozoa: Myxosporida) in Fundulus kansae (Pisces: Cyprinodontidae): Annual prevalence and geographic distribution. Journal of Parasitology 66: 806-810.

Lemly, A. D., AND G. W. Esch. 1984. Population 
biology of the trematode Uvulifer ambloplitis (Hughes, 1927) in juvenile bluegill sunfish, Lepomis macrochirus, and largemouth bass, Micropterus salmoides. Journal of Parasitology 70: 466474.

Margolis, L., G. W. Esch, J. C. Holmes, A. M. Kuris, AND G. A. SCHAD. 1982. The use of ecological terms in parasitology (report of an ad hoc committee of the American Society of Parasitologists). Journal of Parasitology 68: 131-133.

PenNYCUICK, L. 1971. Frequency distributions of parasites in a population of three-spined sticklebacks, Gasterosteus aculeatus L., with particular reference to the negative binomial distribution. Parasitology 63: 389-406.

Poss, S. G., AND R. R. Miller. 1983. Taxonomic status of the plains killifish, Fundulus zebrinus. Copeia 1983: 55-67.

Price, P. 1980. Evolutionary biology of parasites. Princeton University Press, Princeton, New Jersey, 237 p.

1983. Patterns in number of helminth parasite species in freshwater fishes. Journal of Parasitology 69: 449-454.

TAYLOR, L. R., I. P. WOIWOD, AND J. N. PERRY. 1978. The density-dependence of spatial behavior and the rarity of randomness. Journal of Animal Ecology 47: 383-406.

,-- , AND - 1979. The negative binomial as a dynamic ecological model for aggregation, and the density dependence of $\mathrm{k}$. Journal of Animal Ecology 48: 289-304. 